\title{
Regulation of Swine Myogenic Cell Differentiation before the Onset of Fusion
}

\author{
Takahiro Yamaguchi and Haruki Kitazawa* \\ Laboratory of Animal Morphology, Department of \\ Animal Science, Faculty of Agriculture, Tokoku \\ University, Aoba-ka Sendai-shi 981 \\ * Laboratory of Animal Products Chemistry, Department \\ of Animal Science, Faculty of Agriculture, Tohoku \\ University, Aoba-ku, Sendai-shi 981
}

(Received September 27, 1991)

\begin{abstract}
The differentiation of clonal swine myogenic cells, sMc-la, and the concurrent cellular aspects were examined in cultures with swine fetal extract(SFE) and fetal calf serum(FCS). The increase in cell number was maximum in Cp-cultures containing SFE and FCS, and smallest in Se-cultures containing SFE alone. Fe-cultures containing FCS alone gave rise to a substantial increase in the cells although the number was not as many as in Cp-cultures. Twe cell types, spindle-shaped bipolar sMc-la (SB-sMc-1a) and flattened polygonal sMc-1a (FP-sMc-1a), were morphologically distinguished in all cultures. The former was predominant in $\mathrm{Se}$ - and $\mathrm{Cp}$-cultures, and varied from small to large, with some of them extremely elongated. Many large $\mathrm{SB}-\mathrm{SMc}-1 \mathrm{a}$ and small elongated SB-sMc-1a occurred in Se-cultures and Cp-cultures, respectively. The latter was predominant in Fc-cultures and large in size. FP-sMc-1a changed to large SB-sMc-1a when Fc-medium was replaced to Se-medium. Small numbers of small elongated SB-sMc-1a were constantly detected in Fe-cultures. The immunocytochemical reaction of creatine kinase $\mathrm{MM}$ and myosin to be differentiation markers of myoblasts was stronger in small elongated SB-sMc-1a than in large SB-sMc-1a and FP-sMc-1a. The observation indicated that FCS is needed to progress the proliferation of sMc-la and differentiate large SB-sMc-1a into small elongated SB-sMc-1a; and SFE is indispensable to the transition from FP-sMc-la to large SB-sMc-1a. The observation further suggest that FP-sMc-1a are proliferating myoblasts and large SB-sMc-1a are possibly post-mitotic myoblasts.
\end{abstract}

Anim. Sci. Technol. (Jpn.) 63 (4) : 358-367, 1992

Key words: clonal swine myogenic cells, culture condition, immunocytochemistry, differentiation

Cultivated myogenic cells represent an interesting system for the study of a number of fundamental problems in myogenesis. Better and more reliable procedures for the isolation and cultivation of myogenic cells from several kinds of mammals have been provided recent$1 y^{6,15,16)}$. For swine myogenic cells $(\mathrm{sMc})$, we isolated three kinds of clonal myogenic cells -sMc-1, sMc-2 and sMc-3 -from the fetal skeletal muscle and immunocytochemically characterized them wherein sMc-1 and sMc-2 presented typical behaviors of myogenic cells ${ }^{18,19)}$. In the medium supplemented with 10 $\%$ fetal calf serum (FCS) and $1.5 \%$ swine fetal 


\section{Differentiation of $\mathrm{sMc}$}

extract ( $\mathrm{SFE}$ ), it is possible to maintain clonal sMc for several months in a continuous state of replication without loss of differentiation potentialities.

So far, it has been established that the proliferation and differentiation of myogenic cells in cultures is subject to its being controlled by hormone and growth factor in the culture medium ${ }^{3,15)}$. Recently, it has been indicated that components in the medium such as serum and muscle extract are very important in controlling the terminal differentiation of myogenic cells ${ }^{2)}$. Furthermore, it has been observed that fusion takes place only between myoblasts which completed the pre-fusion changes ${ }^{17)}$. However, at the onset of cell differentiation prior to fusion, it has not been fully documented how myogenic cells are influenced by the microenviromental condition of cultures. This report is limited to the cytological changes concurrent to cell differentiation in the early stages of the myogenesis of sMc-1 in the culture system. The results show that swine myogenic cells, sMc-1a, undergo differential changes which are closely associated with the differentiaion under appropriate conditions.

\section{Materials and Methods}

Cell culture: Clonal swine myogenic cell-1a (sMc-1a) were used in this study. The cell was a subline of $\mathrm{sMc}-1$ which were grown in a 1:4 mixture of Dulbecco's minimum essential medium (Nissui Pharmaceutical Co., Ltd., Tokyo. Japan) and M-199 (Nissui Pharmaceutical Co., Ltd.,) supplemented with $10 \%$ fetal calf serum (FCS, preselected for sMc growth) and $1.5 \%$ swine fetal extract (SFE) ${ }^{18)}$. sMc-1a were selected from sMc-1 cultures supplemented with 10\% FCS. Therefore, the cell line readily proliferated more than sMc-1 when FCS was present. A more detailed description of the derivation and characteristics $\mathrm{sMc}-1$ has been described elsewhere ${ }^{18,19)}$.

Cell growth: sMc-1a were cultured in a medium containing different supplements as follows : i) $10 \% \mathrm{FCS}+1.5 \% \mathrm{SFE}$ (complete medium : Cp-medium), ii) $10 \%$ FCS (Fc-medium), iii) $1.5 \% \mathrm{SFE}$ (Se-medium), iv) none (control medium: Ct-medium). The cultures with each medium were designated $\mathrm{Cp}$-cultures, $\mathrm{Fc}$-cultures, Se-cultures and Ct-cultures, respectively. A different number of the cells $\left(3 \times 10^{2}-3 \times 10^{4} / \mathrm{cm}^{2}\right)$ was plated in 24 well culture plates (Sumilon MS-80240, Sumitomo Bakelite Co., Ltd., Tokyo, Japan). On day 3, 5 and 7 , the cells were dissociated by trypsinEDTA solution ${ }^{18)}$, washed and collected. The number was measured by the Coulter Counter (Model ZM System, LU $33 \mathrm{RH}$ England). To evaluate the distinct effect of FCS and SFE on the growth of sMc-la, the cells were incubated in Ct-medium overnight and then maintained in the cultures supplemented with $10 \%$ FCS and $1.5 \% \mathrm{SFE}$ alone for $48 \mathrm{hrs}$ (precultures;

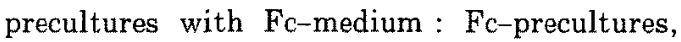
precultures with Se-medium : Se-precultures) and washed three times with $\mathrm{Ct}$-medium. Thereafter, the cells were grown in $\mathrm{Cp}_{-}, \mathrm{Fc}_{\mathrm{c}}$, $\mathrm{Se}-$ and $\mathrm{Ct}$-cultures for another $48 \mathrm{hrs}$ (postcultures). The postcultures containing $\mathrm{Se}-, \mathrm{Fc}-$, $\mathrm{Cp}-$ and $\mathrm{Ct}$-medium were designated $\mathrm{Se}-, \mathrm{Fc}-$, $\mathrm{Cp}$ - and $\mathrm{Ct}$-postcultures, respectively. Finally, the cell number was determined by the method described above.

Morphological and immunocytochemical analysis: sMc-1a were cultured in Lab-Tek chamber slides (4804, Nunc, Inc. Naperville, IL. USA) and washed 3 times with cold buffered saline. Multiple parallel slides of the cultures were analyzed for either morphology and intracellular distribution of myosin or creatine kinase $\mathrm{MM}(\mathrm{CK}-\mathrm{MM})$. The cells were fixed with $10 \%$ buffered formalin, and stained with the periodic acid (PAS) reaction and Mayer's hematoxylin ${ }^{18)}$. The morphology was observed by light microscopy and the percentage of cell types of sMc-1a was dstermined by counting cells ( $>400$ cells) in twenty areas which were randomly selected by square micrometer. For 
the intracellular staining of myosin and $\mathrm{CK}^{-}$ $\mathrm{MM}$, the cells were treated with $0.05 \%$ Nonidet p-40 (Sigma chemical, Co., St. Louis, MO. USA) after fixation and immunohistochemically stained using the Avidin-Biotin complex method which has been reported in detail elsewhere ${ }^{19)}$

Statistics: The statistical difference in mean number of $\mathrm{sMc}-1 \mathrm{a}$ in cultures was determined by the Student's $t$ test.

\section{Results}

Effect of FCS and SFE on sMc-1a growth: Growth kinetics of $\mathrm{sMc}-1 \mathrm{a}$ which was determined by the Coulter Counter was highly reproducible. When sMc-1a were seeded at a concentration of $2 \times 10^{4}$ cells $/ \mathrm{cm}^{2}$ (Fig. 1), the growth rate was the highest in Cp-cultures. On day 7 , the cell number increased by about 12.5 times. A significant increase in the number was also detected in $\mathrm{Fc}$ - and Se-cultures in which the number was always greater in $\mathrm{Fc}-$ cultures than in Se-cultures. On the other hand, sMc-1a number decreased slightly in Ct-cultures with prolonged incubation time. The results indicated that SFE is more ineffective than FCS in progressing sMc-1a proliferation and the maximum proliferation is attained by a combination of SFE and FCS. However, these experiments did not show whether FCS and SFE acted independently or worked together on the growth of sMc-1a. To answer this point, sMc-1a were previously exposed to FCS or SFE alone in precultures, thoroughly washed and then grown in post-cultures containing FCS and/or SFE. In Fc-precultures, the cell number increased by about 2.8 times (Fig. 2-a). The number increased more in subsequent $\mathrm{Cp}-, \mathrm{Fe}-$ and $\mathrm{Se}-$ postcultures. Significantly, the growth rate was extremely enhanced and the cell number rapidly increased in Cp-postcultures in which the number was almost equal to the sum of the number in $\mathrm{Fe}-$ and Se-postcultures. However, in Se-postcultures, the number did not increase over two

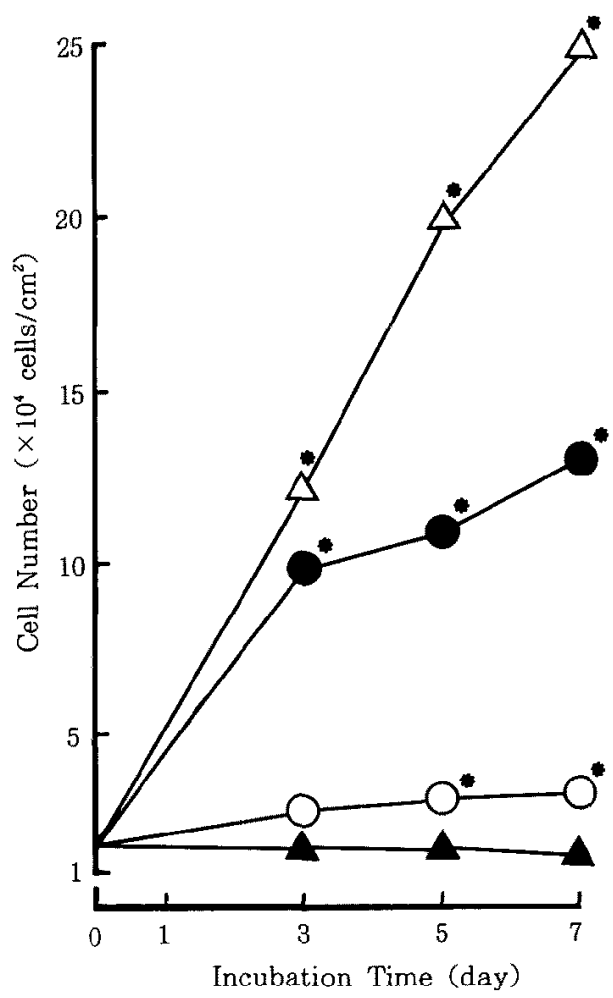

Fig. 1. Effect of SFE and FCS on sMc-1a growth. sMc-1a were cultured in medium with $1.5 \%$ SFE or $10 \%$ FCS alone, and in combination for 7 days.

0 : Se-cultures, $\bigcirc$ : Fc-cultures, $\triangle:$ Cp-cultures, $\Delta$ : Ct-cultures

${ }^{*}: \mathrm{p}<0.01$ (against the number of cells seeded)

times of that of Fc-precultures. No significant increase in the number was detected in Ct-postcultures. On the other hand, in Seprecultures, sMc-1a number did not significantly increase (Fig. 2-b). When the cells were maintained in $\mathrm{Cp}$ - and $\mathrm{Fc}$-postcultures, they started to proliferate. But, Se-postcultures did not result in a significant increase of sMc1a. The observation suggests that SFE is not required for sMc-1a proliferation but it participates in the proliferation in the presence of or after exposure to FCS and FCS progresses the proliferation by itself.

Morphological and immunocytochemical 


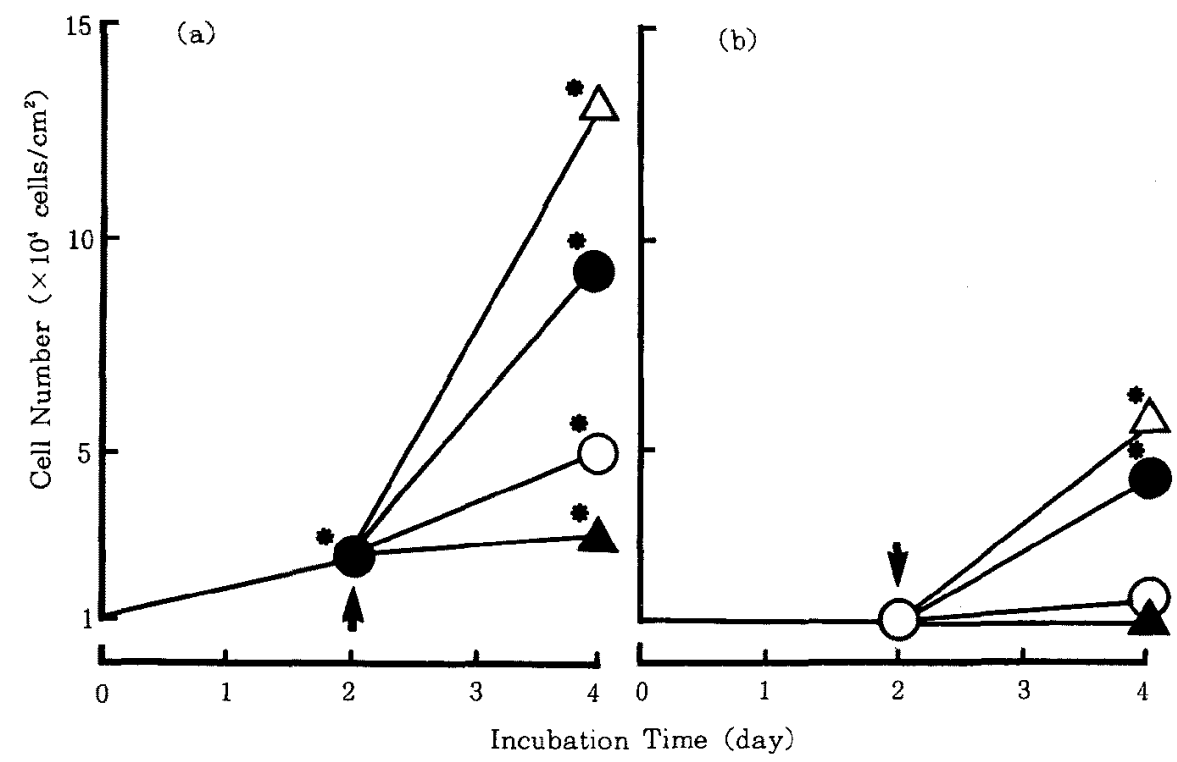

Fig. 2. Different action of SFE and FCS on sMc-1a growth. sMc-1a were exposed to $10 \%$ FCS (a) or 1.5\% SFE (b) alone in precultures for $48 \mathrm{hrs}$, thoroughly washed (arrowed) and grown in postcultures containing 10\% FCS and/or $1.5 \% \mathrm{SFE}$ for an additional $48 \mathrm{hrs}$.

$\bigcirc$ : Se-cultures, $\bigcirc$ : Fc-cultures, $\triangle$ : Cp-cultures, $\boldsymbol{\Delta}$ : Ct-cultures

${ }^{*}: \mathrm{p}<0.01$ (against the number of cells seeded)

Table 1. Effect of SFE and FCS alone and in combination on the appearance of SB-sMc-la

\begin{tabular}{|c|c|c|c|c|}
\hline \multirow{2}{*}{ Postcultures } & \multicolumn{3}{|c|}{ Precultures } & \\
\hline & $\mathrm{Se}$ & & $\mathrm{Fc}$ & \\
\hline $\mathrm{Se}$ & $45.6(+)$ & & $44.7(+$ & $\sim H)$ \\
\hline $\mathrm{Fe}$ & $29.8(+$ & $\sim H)$ & $19.6(+$ & $\sim H)$ \\
\hline Cp & $47.4(+4)$ & & $47.6(H)$ & \\
\hline $\mathrm{Ct}$ & $40.7(+)$ & & $16.4(+$ & $\sim H)$ \\
\hline
\end{tabular}

sMc-1a were incubated in $\mathrm{Se}-$ and $\mathrm{F}_{\mathrm{c}}$-precultures with $1.5 \%$ SFE or $10 \%$ FCS alone for 48 hrs and grown in $\mathrm{Se}^{-}, \mathrm{Fe}^{-}, \mathrm{Cp}-$ and $\mathrm{Ct}$-postcultures for an additional $48 \mathrm{hrs}$.

Data represent $\%$ SB-sMc-la which was calculated as follows: $96 \mathrm{SB}-\mathrm{sMc}-\mathrm{la}=\mathrm{SB}-\mathrm{sMc}-1 /$ total cells $\times 100$.

The degree of appearance of small elongated $\mathrm{SB}-\mathrm{S} M \mathrm{M}-\mathrm{la}$ is indicated in parentheses.

+ : very few, H: few, $H$ : many. changes of sMc-1a by SFE and FCS: In all cultures, two different types of sMc-1a were morphologically distinguished. One type was the flattened polygonal cell (FP-sMc-1a) which was large in size (Fig. 3). The other type was the spindle-shaped bipolar cell (SB-sMc-1a) which was further divided into large SB-sMc1a and small elongated SB-sMc-1a by distinct morphology. The former was poorly stained with PAS reaction and the nuclei were large and oval (Fig. 4). The latter was strongly stained with PAS reaction and extremely elongated (Fig. 5). Large SB-sMc-1a were predominant in Se-precultures. In postcultures subsequent to Se-precultures, the number of SB-sMc-1a was greater in $\mathrm{Se}_{-}-\mathrm{Cp}-$ and $\mathrm{Ct}-$ cultures than that in Fc-cultures (Table 1). Many small elongated SB-sMc-1a occurred in $\mathrm{Cp}$-cultures and very few in Se-cultures (Table 
YAMAGUCHI and KITAZAWA
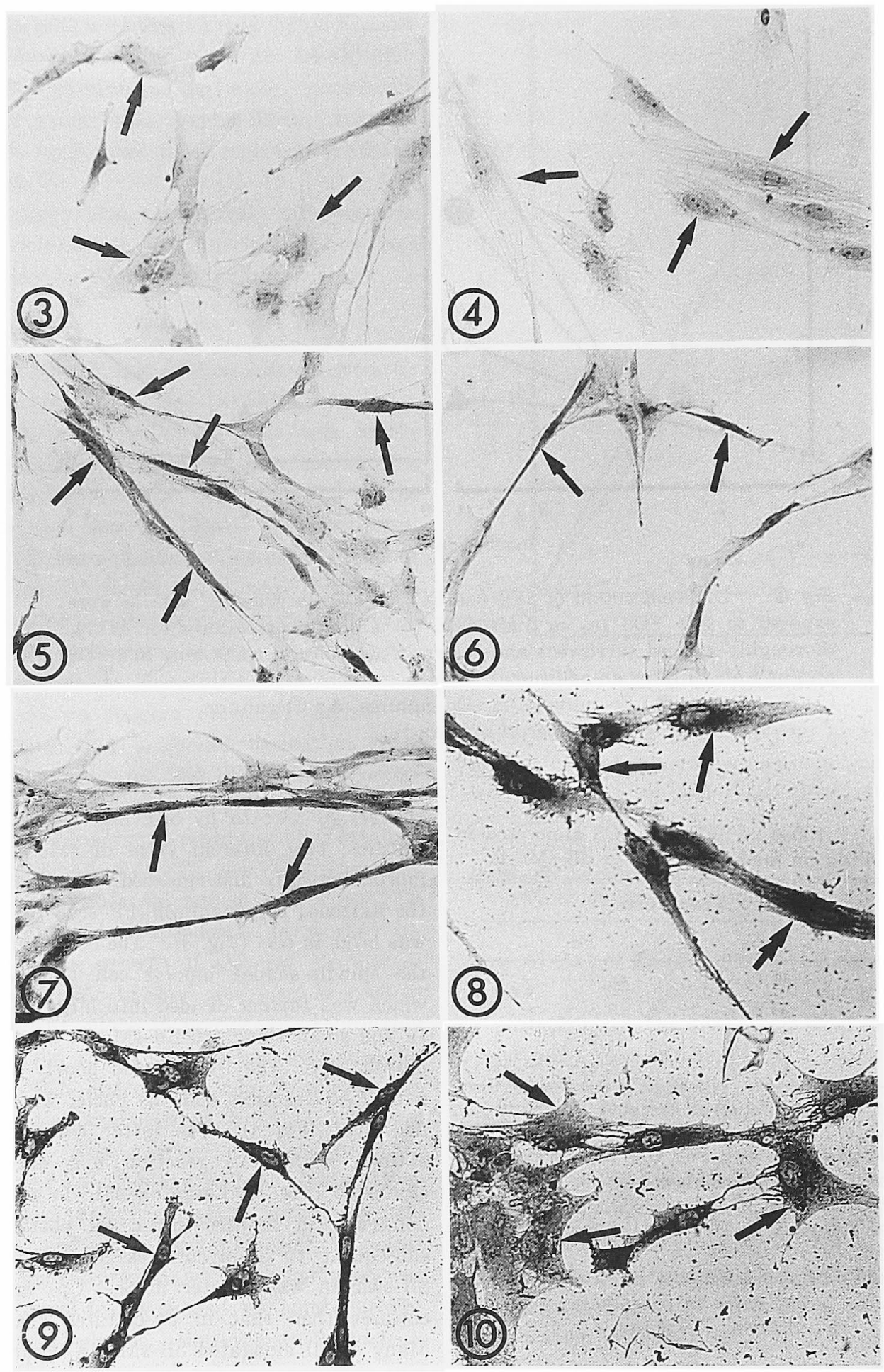


\section{Differentiation of sMc}

1, Fig. 5). In Fc-cultures, although there was less percentage of SB-sMc-1a, FP-sMc-1a were predominant and a small number of small elongated SB-sMc-1a were constantly detected (Fig. 6). In contrast, a lot of FP-sMc-1a was detected in Fc-precultures. In subsequent postcultures, SB-sMc-1a increased in number in Seand $\mathrm{Cp}$-cultures where many elongated SBsMc-1a occurred in Cp-cultures (Table 1). However, even when $\mathrm{Fe}$-precultures were maintained as Fe-postcultures, about $20 \%$ of SBsMc-1a containing a small number of small elongated SB-sMc-1a were constantly yielded (Table 1). On the other hand, an alignment which is the apposition of the long axes of small elongated SB-sMc-1a were formed frequently in Cp-postcultures (Fig. 7) and occasionally in $\mathrm{Fe}$-postcultures but not in $\mathrm{Se}-$ postcultures. The results support that i) an exposure to SFE augments the appearance of large SB-sMc-1a, ii) small elongated SB-sMc1a generate in the presence of FCS rather than of SFE, iii) FCS has an ability to progress FP-sMc-1a proliferation and stimulate the formation of alignments of small elongated SB-sMc-1a.

To determine the stages of FP-sMc-1a and SB-sMc-1a during the early differentiation, intracellular myosin and $\mathrm{CK}-\mathrm{MM}$ which are clcsely associated with the differentiation of $\mathrm{sMc}^{6)}$ were immunocytochemically examined. Both the proteins were diffusely posititve in the cytoplasm of SB-sMc-1a and FP-sMc-1a. The reaction product intensity of $\mathrm{CK}-\mathrm{MM}$ was heterogeneous, varying considerably between SB-sMc-1a. The intensity was weak to moderate in large SB-sMc-1 a (Fig. 8) and moderate to very strong in small elongated SB-sMc-1a (Fig. 9). In contrast, the reaction was weak in $\mathrm{FP}-\mathrm{sMc}-1 \mathrm{a}$. The reaction products in large SB-sMc-1a and FP-sMc-1a frequently located around the nuclei (Figs. 8, 10). The immunocytochemical experiment for myosin gave almost similar results as the $\mathrm{CK}-\mathrm{MM}$ experiment. (Fig. 11, 12) The results suggest that large SB-sMc-1a with the relatively weak intensity of CK-MM and myosin are immature postmitotic sMc-1a and differentiate into small elongated sMc-la which were stained more strongly with the antibodies, and FP-sMc1a which were weakly stained immunocytochemically are proliferating sMc-1a.

\section{Discussion}

Relatively crude components such as serum $^{6,16)}$, chick embryo extract $(\mathrm{CEE})^{5,11,16)}$ and brain extract ${ }^{4,16)}$ have been widely employed as growth-prompting supplements for cultures of

Fig. 3. SB-sMc-1a in Se-precultures $(\swarrow)$. SB-sMc-la are large in size and the nuclei are large and oval. $\times 200$.

Fig. 4. FP-sMc-1a in Fc-precultures $(\swarrow)$. The cells are large in size and frequently observe as a mass. $\times 200$.

Fig. 5. Small elongated SB-sMc-1a in Cp-postcultures $(\swarrow)$. The cytoplasm is strongly stained with PAS reaction. $\times 200$.

Fig. 6. Small elongated SB-sMc-1a in Cp-postcultures $(\swarrow)$. The morphology are very similar to those in Fig. 5. $\times 200$.

Fig. 7. The alignments formed by small elongated SB-sMc-1a in $\mathrm{Cp}$-postcultures $(\measuredangle)$. $\times 200$.

Fig. 8. Immunocytochemical reaction for CK-MM of large SB-sMc-la in Seprecultures. CK-MM is stained weakly $(\swarrow)$ to moderately $(\swarrow)$ and distributed frequently around nuclei, $\times 200$.

Fig. 9. Immunocytochemical reaction for CK-MM of small elongated SB-sMc-1a $(\measuredangle)$. The cytoplasm of cells which present in $\mathrm{Cp}$-postcultures are very strongly stained. $\times 200$. Fig. 10. FP-sMc-1a with CK-MM weakly stained by the immunocytochemical reaction in Fc-precultures $(\swarrow)$. The reaction products are predominantly distributed around nuclei. $\times 200$. 


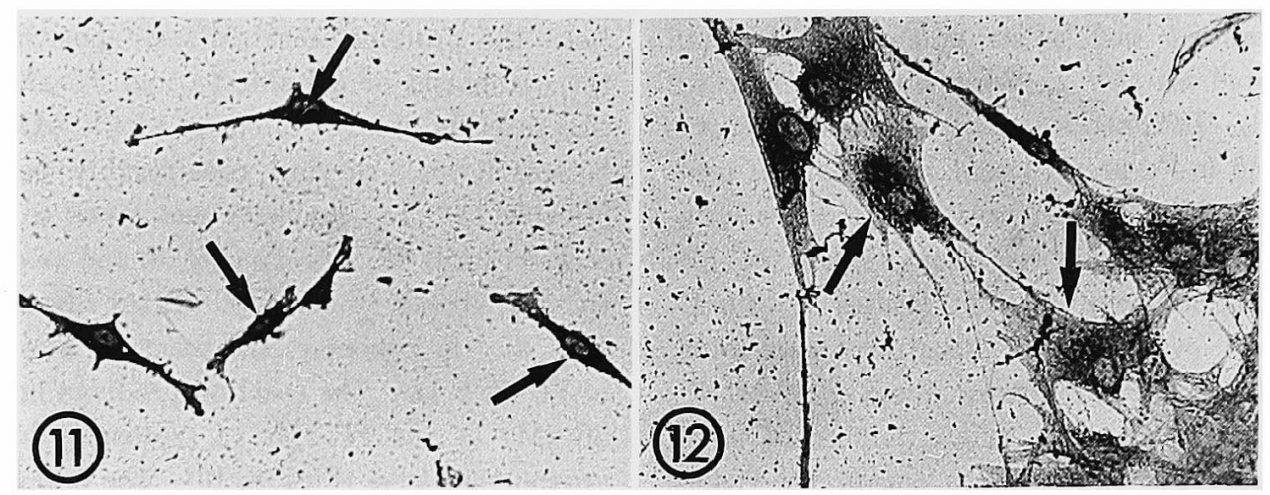

Fig. 11. Immunocytochemical reaction for myosin of small elongated SB-sMc-1a in Cp-postcultures $(\swarrow) . \times 200$.

Fig. 12. FP-sMc-1a stained weakly positive by the immunocytochemical reaction for myosin in Fc-precultures $(\swarrow) . \times 200$.

myogenic cells. Neither serum nor CEE alone is able to induce proliferation of freshly isolated myogenic cells ${ }^{5,16)}$. In many cases of myogenic cell cultures, CEE is generally added as an indispensable supplement to a medium containing serum ${ }^{2,16}$. We have found that SFE can substitute for CEE as a growth-promoting supplement for sMc cultures ${ }^{18)}$. However, the studies did not provide the distinct role of $\mathrm{CEE}$ and serum on the proliferation and differentiaion of sMc-1 in the culture system. In this paper, we have shown that FCS has a tropic activity which progress the proliferation of sMc-1a. An addition of SFE to Fc-cultures potentiated the tropic activity although any tropic activity to $\mathrm{sMc}-1 \mathrm{a}$ was not induced in Se-precultures. The effects of SFE did not result in over twice increases of the cell number in Fc-precultures. The findings imply that FCS has a substantial tropic activity for sMc-1a proliferation and sMc-1a are able to complete one round of the cell cycle when sMc-1a were exposed to SFE after Fc-cultures. sMc-1a, unlike primary culture cells, were adapted to and selected from the cultures containing FCS. Therefore, it can be understood that they readily proliferate in the presence of FCS alone.
In addition, SFE may participate in the induction of postmitotic myoblasts ${ }^{10,15)}$ from proliferating myoblasts ${ }^{10,15)}$ since SFE ceased the proliferation without the loss of cell viability.

The first part of myogenic differentiation is that proliferaing myoblasts are converted to postmitotic myoblasts ${ }^{8)}$ which are irreversibly committed to subsequent myogenic differentiation $^{9)}$. The induction of postmitotic myoblasts is very important in understanding terminal differentiation. At present, morphological aspects of postmitotic myoblasts and proliferating myoblasts have not been fully understood. Morphological and immunocytochemical approaches in this study were available to characterize the differentiated sMc-1a. CK-MM and myosin as markers of the differentiation of sMc-1a were selected because both proteins are muscle-specific gene products ${ }^{1,11,13,14)}$ and immunohistochemical procedures permit their detection in single cells ${ }^{1,13)}$. FP-sMc-1a, large SB-sMc-1a and small elongated SB-sMc-1a were distinctly distinguished by their morphology and staining. Large SB-sMc-1a were predominant in Se-precultures which sMc-1a could not proliferate. The majority of FPsMc-1a present in great numbers in Fc-pre- 


\section{Differentiation of $\mathrm{sMc}$}

cultures which induced a substantial proliferation of sMc-la were changeable to large SBsMc-1a in Se-postcultures. The observation offeres the prospect that $\mathrm{FP}-\mathrm{sMC}-1 \mathrm{a}$ are proliferating myblasts and large SB-sMc-la may be postmitotic myoblasts generated from FPsMc-1a. However, large SB-sMc-la and FPsMc-1a were not clearly distinguishable by both the reaction intensity of CK-MM and myosin.

Another observation made in this experiment was about the appearance of small elongated sMc-1a. The cells constantly occurred in $\mathrm{Fe}$ precultures but not in Se-cultures. The number increased in $\mathrm{Cp}$-postcultures after Seprecultures and the cells aligned frequently. The intracellular reaction of $\mathrm{CK}^{-} \mathrm{MM}$ and myosin was stronger in small elongated SB-sMcla than in large SB-sMc-1a. Since myogenic differentiation has been measured as an increased expression of muscle cell functions such as $\mathrm{CK}-\mathrm{MM}$ activity ${ }^{33}$, we concluded that large $\mathrm{SB}-\mathrm{sMc}-1 \mathrm{a}$ in Se-precultures are immature postmitotic myoblasts and become small elongated SB-sMc-la which are probably fully developed postmitotic myoblasts in the presence of FCS.

The main effect of CEE on myogenic cells is a nonspecific enhancement of prolifera$\operatorname{tion}^{5,6,11,16)}$ in which transferrin ${ }^{5,11}$ and other substances ${ }^{5,16)}$ effectively cause myotropic activity. However, it has been clarified how myogenic cells repond to the substances in CEE. The recent finding indicates that muscle extract commit quiescent satellite cells to divide, whereas serum factors are needed to maintain progression through the cell cycle when both the components are simultaneously added to the cultures ${ }^{2}$. In this study, an addition of SFE to the medium containing FCS produced maximum proliferation of sMc-1a. This pointed out a possibility that SFE are not required for the differentiation of $\mathrm{sMc}-1 \mathrm{a}$ but also the proliferation. To elucidate such different action of SFE, it is necessary to conduct comparative experiments with other growth supplements such as CEE and muscle extract, and further isolate effective factor(s) from SFE.

Our results provide differential rules of SFE and FCS on the differentiation of sMc-1a in the early stages prior to the onset of cell fusion. FCS is needed for the progression of the cell cycle of FP-sMc-1a and further differentiation of large SB-sMc-1a. SFE is indispensable for the transition from $\mathrm{FP}-\mathrm{SMc}$ 1a to large SB-sMc-1a. Further studies remain to demonstrate the inducible mechanism of large SB-sMc-1a.

\section{Acknowledgment}

This study was supported by a Grant-in-Aid (No. 02806049) from the Ministry of Education, Science and Culture of Japan to Dr. T. YAMAGUCHI.

\section{References}

1) Bayne, E.K. and S.B. Simpson, JR., Detection of myosin in Prefusion $\mathrm{G}_{0}$ lizard myoblasts in vitro. Develop. Biol., 55 : 306319. 1977.

2) Bischoff.R., Cell cycle commitment of rat muscle satellite cells. J. Cell Biol., 111: 201-207. 1990.

3) Florini, J.R. and K.A. MAGRi, Effects of growth factors on myogenesis differentation. Am. J. Physiol., 256 : C 701-711. 1989.

4) Gospodarowicz, D., J. Weseman and J. Moran, Presence in brain of a mitogenic agent promoting Proliferation of myoblasts in low density culture. Nature, 256 : 216-219. 1975.

5) II, I., I. Kimura, and E. Ozawa A myotrophic protein from chick embryo Extract: Its purification, identity to transferrin, and indispensability for avian myogenesis. Develop. Biol., 94 : 366 377. 1982.

6) Konigsberg, I.R., Skeletal myoblasts in culture. Methods in Enzymology, Vol. L VIII. 511-527. Academic Press, Inc., 1979.

7) Mertie, J.P. and F. Gros, In vitro myogenesis : Expression of muscle specific function in the absence of cell fusion. Exp. Cell Res., 97 : 406-412. 1976. 


\section{YamaGuchi and KitAZAWA}

8) NadaL-Ginard, B., Commitment, fusion, and biochemical differentiation of a myogenic cell line. Cell, 15 : 855-863. 1978.

9) NGuyen, H.T., R.M. Medford and B. NADAL-GINARD, Reversibility of muscle differentiation in the absence of commitment: analysis of a myogenic cell line temperature-sensitive for commitment. Cell, 34 : 281-293, 1983

10) QUinN, L.S., L.D. ONG and R.A. RoEDER, Paracrine control of myoblast proliferation and differentiation by fibroblasts. Develop. Biol., 40 : 8-19. 1990.

11) Slater, C.R., Control of myogenesis in vitro by chick embryo extract. Develop. Biol., 50 : 264-284. 1976.

12) TURNer, D.C., V. MaIER and H.M. EPPENBerger, Creatine Kinase and aldolase isoenzyme transition in cultures of chick skeletal muscle cells. Develop. Biol., $37: 63-89.1974$.

13) Turner, D.C., R. Gmur, H.G. Lebererz, M. Siegrist, T. Wallimann and H.M. EPPENBERGER, Differentiation in cultures drived from embryonic chicken muscle: II.
Phosphorylase histochemistry and fluorescent antibody staining for creatine kinase and aldolase. Develop. Biol., 48 : 284-307. 1976.

14) Vertel, B.M. and D.A. Fischman, Myosin accumulation in mononucleated cells of chick muscle cultures. Develop. Biol., 48 : 438-446. 1976.

15) WAKELAM, M.J. O., The fusion of myoblasts. Biochem. J. $228: 1-12.1985$.

16) WıткошsкI, J.A., Diseased muscle cells in culture. Biol. Rev., 52 : 431-471. 1977.

17) Y $\mathrm{AFFE}, \mathrm{D}$., Developmental changes preceding cell fusion during muscle differentiation in vitro. Exp. Cell Res., 66: 33-48. 1971.

18) Yamaguchi, T., H.Kitazawa and $T$. Hoshino, Long-term culture of swine myogenic cells. Anim. Sci. Technol (Jpn), 62: 620-627. 1991.

19) Yamaguchi, T. and T. Hoshino, Cytochemical characteristics of clonal myogenic cells derived from swine skeletal muscle. Anim. Sci. Technol (Jpn), 63 : 8-15, 1991. 


\title{
Differentiation of $\mathrm{sMc}$
}

\section{筋発生初期に㧍けるブ夕筋原細胞の分化調節}

\author{
山口高弘・北澤春樹
}

東北大学農学部，仙台市青葉区 981

\begin{abstract}
クローン化ブタ筋原細胞（sMc-1a）の分化およびをれに伴う細胞性状をブ夕胎児抽出物（SFE） あるいはりシ胎児血清（FCS）を添加した培養系で研究した，sMc-1a の増殖は SFE とFCS を共に 含む培養 ( $\mathrm{Cp}$-培養) で最も著しく、 SFE ドけを含む培養（Se-培䓹）ではほとんど起こらなかった， FCS だけを含む培養（Fe-培養）では $\mathrm{Cp}$-培養ほどではないが細胞增殖が生じた。紡錘系で両極性の 細胞（SB-sMc-1a）女平板状で多角形の細胞（FP-sMc-1a）がすべての培善系で形態学的に区別で きた。SB-sMc-1a は Se- と Cp-培養で数多く，小型ないし大型と変化し，さらに細長い細胞が確認 できた. 大型 SB-sMc-1a は Se-培湌で，小型の細長い SB-sMc-1aは $\mathrm{Cp}$-培養で数多く出現した。 FP-sMc-1a は大型で Fe-培養で数多く，その後の Se-培盖で大型の SB-sMc-1a に変化した，少数 の小型で細長い SB-sMc-1a が常に $\mathrm{Fe}$-培養に存在した．筋原細胞の分化指標であるクレアチンホス ホキナーゼ MM 抢よびミオシン蛋白は免度細胞組織学的に小型で細長い SB-sMc-1aにおいて大型 SB-sMc-1a および FP-sMc-1a より強い陽性反応走した。

以上の結果は FCS は sMc-1a の增殖の維持と大型 SB-sMc-1a が SB-sMc-1a 分化するのに必要 であり，SFEは FP-sMc-1a が大型の SB-sMc-1aに移行する際に不可父むることを示す。FPsMc-1a は分裂可能な筋芽細胞前駆絸胞（proliferating myoblast precursors）で, 大型 SB-sMc1a は小型の細長い SB-sMc-1a に分化できる筋芽細胞（postmitotic myoblasts）である可能性を 示唆する.
\end{abstract}

日畜会報，63 (4)：358-367, 1992 